\title{
Foreword
}

\section{George David}

The idea of this book originated in a conversation I had several years ago at a Bilderberg meeting in Scotland with Margaret MacMillan, Professor of History at the University of Toronto. Margaret, a great scholar of the 1919 Paris Peace Conference, was keenly aware of the role played by Eleftherios Venizelos in the meetings that redrew the political map of Europe and expressed an interest in reading more about him and his policies. I promised to send her books in English to satisfy her curiosity, which I understood had also to do with the close personal friendship between Venizelos and her great grandfather David Lloyd George.

When I returned to Greece I called a close friend, Paschalis Kitromilides, Professor of Political Science at the University of Athens and asked him to suggest some works on Venizelos in English. He chuckled on the phone and told me that the latest book in English on Venizelos had been published by our Cypriot compatriot Doros Alastos as far back as 1942. I was both slightly shocked and amused by the revelation. This gave me the idea that under the aegis of the A. G. Leventis Foundation a new book presenting a profile of Venizelos as leader, statesman and reformer of Greek society could be published. For this undertaking I thought there was no one better than Professor Kitromilides himself, a well-established and respected authority on modern Greek history and politics. I therefore asked him to organise the project in his capacity as Director of the Institute for Neohellenic Research at the National Hellenic Research Foundation. The present book is the result of his strenuous effort to co-ordinate a group of distinguished authorities on Venizelos in the community of scholars on Greece.

On behalf of the A. G. Leventis Foundation I am pleased and proud that we have contributed to the filling of a serious gap in the knowledge of modern Greece of English-reading scholars and of a broader cultivated international public interested in the history, politics and biography of twentieth-century Europe. I wish to express my appreciation to all those who have contributed to turning into reality this vision to honour the man who has strong claims to be considered Greece's greatest statesman of the twentieth century. 